\title{
Hydrogeochemistry of high-fluoride saline groundwater in the Yuncheng Basin, northern China
}

\author{
Chengcheng $\mathrm{Li}^{1}$, Xubo $\mathrm{Gao}^{1, *}$, Yanxin Wang ${ }^{1}$, and Ken Howard ${ }^{2}$ \\ ${ }^{1}$ School of Environmental Studies, China University of Geosciences, Wuhan 430074, China \\ ${ }^{2}$ Groundwater Research Group, University of Toronto at Scarborough, Scarborough, ON, Canada
}

\begin{abstract}
The presence of saline groundwater has become one of the most acute problems for water resource management worldwide, since it causes deterioration in water quality and endangers future exploitation of groundwater resources. In addition, high levels of groundwater salinity are often associated with an increase in the concentrations of fluoride $(F)$. Diverse mechanisms govern salts and fluoride enrichment in groundwater. In this case, saline groundwater with elevated fluoride (up to $14.1 \mathrm{mg} / \mathrm{L}$ ) in the Yuncheng Basin (YB) was investigated. The research shows: (i) largescale contamination of $\mathrm{F}$ in groundwater is closely associated with groundwater salinization processes in the area; (ii) groundwater with high $\mathrm{F}$ concentrations has distinctive major ion chemistry: Na-rich and Ca-poor with a high $\mathrm{pH}$ and $\mathrm{HCO}_{3}{ }^{-}$content. The major ion chemistry and $\mathrm{pH}$ are controlled by mineral dissolution, cation exchange, and evaporation in the aquifer systems which are also important for F mobilization.
\end{abstract}

\section{Introduction}

In inland regions, especially arid/semi-arid regions, groundwater constitutes the largest available source of freshwater. However, groundwater quality frequently fails to meet the requirement for potable water supply due to natural processes and/or anthropogenic activities that affect water composition. The presence of saline groundwater is one of the most conspicuous problems globally, especially in water-scarce areas. High salinity contents in groundwater seriously restrict its domestic, agricultural, and industrial uses. In addition, groundwater salinization is often associated with high levels of total or specific dissolved constituents other than sodium and chloride [1]. For instance, in many parts of China, eastern Africa and India, elevated fluoride contents are related with overall groundwater salinity and cause prevailing dental and skeletal fluorosis. High concentrations of fluoride have been detected in the saline groundwater from Quaternary aquifers in the Yuncheng Basin (YB), a typical area in semi-arid northern China, where groundwater plays a vital role as a water supply for irrigation and drinking. Endemic fluorosis at YB was first confirmed in 1980s and severe fluorosis cases have been identified in more than $20 \%$ of the villages in Linyi County [2]. The geology, hydrogeology, circulation pattern of

* Corresponding author: xubo.gao.cug@gmail.com 
groundwater, and hydrogeochemistry of elevated fluoride and arsenic groundwater in YB have been well studied. However, little is known about the natural and anthropogenic processes that control the salts and fluoride enrichment in groundwater.

The Yuncheng basin is composed of Quaternary sediments $\left(Q_{1}-Q_{4}\right)$, primarily aeolian loess, lacustrine clays, fluvial sands and gravels. The Quaternary loess mostly contains quartz, feldspar, calcite, clays, and mica. The Quaternary groundwater system can be divided into two unconsolidated units: a shallow unconfined unit $\left(<70 \mathrm{~m}, \mathrm{Q}_{3}\right.$ and locally $\mathrm{Q}_{4}$ ), and a semi-confined deep unit $\left(>120 \mathrm{~m}, \mathrm{Q}_{1}\right.$ and locally $\left.\mathrm{Q}_{2}\right)$. The shallow unit is distributed in the Sushui River Basin. The thickness of this aquifer is generally $6-20 \mathrm{~m}$. The deep unit is distributed within the whole basin range. These two units are separated by the S1 palaeosol [3], which extends laterally throughout much of the basin and is a partial barrier to vertical mixing between the units. A separate intermediate unit may also exist between $70 \mathrm{~m}$ and $120 \mathrm{~m}$, although this unit is essentially part of the deep unit [4].

Historically, regional groundwater flows from eastern YB to the west, towards the Yellow River, while intermediate-scale flow occurs from the sloping southern and northern margins to the central areas of the basin [5]. However, due to the over-exploitation of groundwater since the 1980s, horizontal groundwater flow now turns towards a cone of depression to the west of Yuncheng city. The groundwater in this Basin is mainly recharged by vertical seepage of meteoric water and by lateral permeation of fissure water along the basin margin. Leakage of non-perennial river water and irrigation return are additional sources of groundwater recharge. Evapotranspiration and artificial abstraction are the major ways of groundwater discharge.

\section{Methods and materials}

One hundred groundwater samples were collected across the YB in August 2014. Among them, 26 samples were collected from shallow wells ( 9 to $50 \mathrm{~m}$ ), 58 from deep wells (130 to $500 \mathrm{~m}$ ) and 16 from intermediate aquifers $(80$ to $120 \mathrm{~m})$. Before sampling, the groundwater was pumped for a significant amount of time till the unstable parameters were stabilized. At the time of sampling, all the groundwater samples were filtered through $0.45 \mathrm{um}$ membranes on site and stored in three new $500 \mathrm{~mL}$ polyethylene bottles that had been pre-cleaned with deionized water and rinsed with extracted water at least three times. Samples for analysis of cations and trace elements were preserved by acidification with reagent-quality nitric acid $\left(\mathrm{HNO}_{3}\right)$ to $\mathrm{pH}<2$, while those for other analysis were untreated. Unstable parameters like temperature (T), $\mathrm{pH}$ and electrical conductivity (EC) were monitored in situ using portable Hanna EC and $\mathrm{pH}$ meters that had been calibrated before use. Alkalinity was determined using the Gran titration method on the sampling day [6]. Concentrations of anions including F were determined using IC (Dionex 120). An Intrepid II XSP ICP-AES was used for cation and trace elements measurements.

\section{Results and discussion}

\subsection{Distribution and hydrogeochemistry of F-rich saline groundwater}

Groundwater $\mathrm{pH}$ ranged from 7.11 to 8.55 , with a median value of 8.10 , indicating near-neutral to weakly alkaline conditions. For all groundwater samples, the range of TDS contents is quite wide, being 274 to $9597 \mathrm{mg} / \mathrm{L}$, with $68 \%$ of groundwater samples having brackish or saline character according to the Freeze and Cherry classification [7]. Concentrations of $\mathrm{F}^{-}$vary from 0.2 to $14.1 \mathrm{mg} / \mathrm{L}$. In the shallow aquifers, the $\mathrm{F}^{-}$varies between 0.5 and $14.1 \mathrm{mg} / \mathrm{L}$, with a median value of $3.8 \mathrm{mg} / \mathrm{L}$ observed. Over $69 \%$ of the shallow wells have $\mathrm{F}^{-}$concentrations above the WHO drinking guideline of $1.5 \mathrm{mg} / \mathrm{L}$ and $85 \%$ of the wells have $\mathrm{F}^{-}$concentrations above the Chinese MCL level of $1.0 \mathrm{mg} / \mathrm{L}$ Groundwater samples from the intermediate and 
deep aquifers have lower $\mathrm{F}^{-}$concentrations, ranging from 0.4 to $3.2 \mathrm{mg} / \mathrm{L}$ and from 0.2 to 4.2 $\mathrm{mg} / \mathrm{L}$, respectively. The only exception is one deep hot groundwater sample that has a $\mathrm{F}^{-}$ concentration of $8.2 \mathrm{mg} / \mathrm{L}$. Nevertheless, $44 \%$ of the samples from the intermediate and $31 \%$ of the samples from the deep aquifers are still above the $1.5 \mathrm{mg} / \mathrm{L}$ threshold.

Distinct hydrochemical characteristics are recorded in groundwater from YB. The majority of samples in shallow aquifers (74\%), and intermediate and deep aquifers (58\%) fall under the subdivision of alkali metals and strong acidic anions that exceed both alkaline earths and weak acidic anions ( $\mathrm{Na}-\mathrm{Cl}-\mathrm{SO}_{4}$ type). Few samples belong to $\mathrm{Ca}-\mathrm{Mg}-\mathrm{Cl}-\mathrm{SO}_{4}$ type. These indicate severe groundwater salinization problems in the study area. F-enriched groundwater mainly occurs in the saline water zones, suggesting the possible concomitance of fluoride and salinity.

\subsection{Formation of high-F saline groundwater}

High-F groundwater at YB has distinctive major ion chemistry: generally Na-rich and Capoor with relatively high $\mathrm{pH}$ and $\mathrm{HCO}_{3}{ }^{-}$concentrations (Fig. 1). Fluoride in the groundwater may be derived from the dissolution of fluorine-bearing minerals and the desorption of exchangeable $\mathrm{F}$ from the loess [8]. In this area, hard rocks, such as granodiorite, porphyrite, gneiss, amphibolite and phosphorite, contain plentiful fluorinebearing minerals, including fluorite, hornblende and apatite [9]. As one of the major fluorinebearing natural minerals, fluorite dissolves rapidly under natural conditions, even when its solubility is low. A fast increase in the F concentration in the aqueous solution was observed over 7 days in the indoor experiment performed by [10]. Because the fluorine-bearing minerals are sparingly soluble, the presence of high $\mathrm{F}$ concentrations in the groundwater requires a long residence time, which is possible in the central parts of $\mathrm{YB}$, where the average residence time of the shallow groundwater is estimated to be over 1000 years.

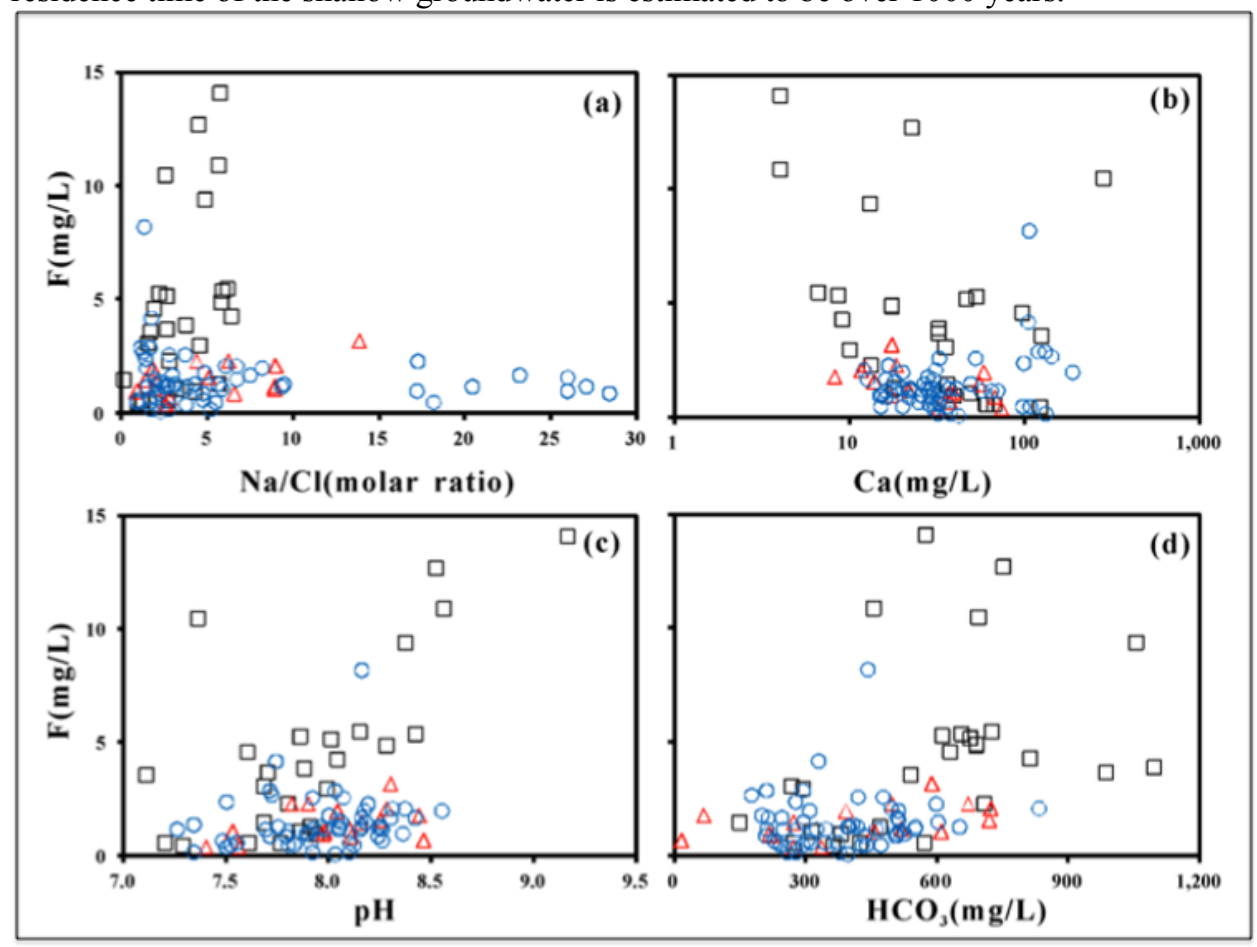

Fig. 1. Plots of $\mathrm{Na} / \mathrm{Ca}$ vs. $\mathrm{F}^{-}(\mathrm{a}), \mathrm{Ca}^{2+}$ vs. $\mathrm{F}(\mathrm{b}){ }^{-} \mathrm{pH}$ vs. $\mathrm{F}^{-}(\mathrm{c}), \mathrm{HCO}_{3}{ }^{-}$vs. $\mathrm{F}^{-}$(d) in $\mathrm{YB}$ groundwater. Legend for groundwater samples: $\square$ shallow, $\Delta$ intermediate, $\circ$ deep. 
Leachable or exchangeable $\mathrm{F}$ is another important source of $\mathrm{F}$ in groundwater, even though it may only account for a small proportion of the total fluorine in aquifer materials. It has been observed that some metal oxides and oxyhydroxides (e.g., $\left.\mathrm{Al}_{2} \mathrm{O}_{3}, \mathrm{Fe}(\mathrm{OH})_{2}\right)$ can adsorb a number of anions, including $F$ [11]. The adsorption of $F$ onto these metal oxyhydroxides occurs when $\mathrm{F}$ replaces surface hydroxyls. Thus, the adsorption of $\mathrm{F}$ preferentially occurs under neutral to acidic conditions. Alkaline $\mathrm{pH}$ condition is favorable for $\mathrm{F}$ desorption from the sediment matrix. At high $\mathrm{pH}, \mathrm{OH}^{-}$can displace $\mathrm{F}$ ions and results in the desorption of $\mathrm{F}$ into the aqueous phase or limits the $\mathrm{F}$ sorption capacity.

Cation exchange promotes the release of $\mathrm{F}$ from the sediments into the groundwater in the YB. Along flow paths within the basin, most groundwater becomes enriched in sodium due to cation exchange (Fig. 1a). Several studies have demonstrated that a change from Carich to Na-rich groundwater results in dissolution of more $\mathrm{F}$ from the mineral phase into the aqueous solution [2]. There are two reasons for this. First, the positive surface charges of the hydrous metal oxide solids can increase due to the presence of $\mathrm{Ca}^{2+}$ rather than $\mathrm{Na}^{+}$. This has been confirmed by the laboratory experiment [11]. An increase of positive surface charge would result in stronger sorption with the negatively charged $\mathrm{F}^{-}$. The presence of $\mathrm{Na}^{+}$(as opposed to $\mathrm{Ca}^{2+}$ ) facilitates fluorine desorption. Thus, the composition of Na-rich groundwater results in fluorine mobilization. Second, higher $\mathrm{Ca}^{2+}$ conditions promote fluorite precipitation, which limits the amount of $\mathrm{F}$ in the groundwater and favors sorption.

The competitive anions, such as $\mathrm{HCO}_{3}^{-}$, promote the formation of high-F groundwater under alkaline conditions in the $\mathrm{YB}$. High $\mathrm{HCO}_{3}{ }^{-}$contents enable high $\mathrm{F}$ concentrations in groundwater of Quaternary loess regions [11]. In YB, the sediment is mostly aeolian loess containing quartz, feldspar, calcite, clays, and mica. Significant iron and aluminum oxides, such as goethite and bauxite, were detected in loess samples from Yuncheng [13]. The F in these sediments was mainly associated with these metal oxides. $\mathrm{HCO}_{3}^{-}$appears to be a strong competitor for sorption [11]. Such adsorbed F can be desorbed from the sorption sites and enter the groundwater when the $\mathrm{HCO}_{3}{ }^{-}$concentrations are high under alkaline conditions, which reasonably explains why YB groundwater samples with elevated $\mathrm{pH}$ values and $\mathrm{HCO}_{3}{ }^{-}$concentrations have elevated $\mathrm{F}$ concentrations.

Evaporation is another possible factor that can influence the occurrence of $\mathrm{F}$ in shallow groundwater. Evaporation processes tend to increase the concentrations of all species in the groundwater, including $\mathrm{F}$. The effects of evaporation on groundwater $\mathrm{F}$ concentration can be understood in two aspects. First, evaporation tends to concentrate F in groundwater by removing water from the aquifers. Second, evaporation causes oversaturation with respect to $\mathrm{CaCO}_{3}$, which may remove $\mathrm{Ca}^{2+}$ and promote further dissolution of fluorine-bearing minerals (such as fluorite and fluorapatite) and release of $\mathrm{F}$ into groundwater.

\section{Conclusions}

Groundwater salinization deteriorates the water quality; moreover, it is often associated with high levels of health-related inorganic constituents, like F. High-fluoride saline groundwater mainly occurs in shallow Quaternary aquifers at the YB. High-F groundwater has distinct major ion chemistry: Na-rich and Ca-poor, with high $\mathrm{pH}$ and $\mathrm{HCO}_{3}{ }^{-}$values. Such characteristics of groundwater chemistry are closely related to salinization processes of mineral dissolution, cation exchange, and evaporation in the aquifer systems.

Acknowledgements. This research was financially supported by the National Natural Science Foundation of China (No. 41120124003 \& No. 41372251), China Postdoctoral Science Foundation (2018M642944) and the International Postdoctoral Exchange Fellowship Program by the Office of China Postdoctoral Council. 


\section{References}

1. A. Vengosh, Treatise on Geochemistry, 9, 325-368 (2005)

2. X.B. Gao, et al.,, Environ Geol, 53, 4-14 (2007)

3. T.S. Liu, et al., Quat Sci Rev, 5, 3-16 (1986)

4. X.H. Cao, Shanxi Hydrotech, 3, 8-12 (2005)

5. Yuncheng Regional Water Bureau, Shanxi province Geological Survey, Hydrological and Geological maps and explanations for the Yuncheng region, 1:100000, (1982)

6. G. Gran. Act. Chem. Scand., 3, 559-577 (1950)

7. R.A. Freeze, J.A. Cherry. Groundwater, Prentice-Hall, Englewood Cliffs, NJ, (1979)

8. R.B. Wanty, et al., Proce $7^{\text {th }}$ Int WRI Symp 599-602 (1992)

9. H.X. Hu, J.L. Guo, Inv Sci Tech, 3, 32-45 (1992)

10. V.K. Saxena, S. Ahmed, Env Geol, 40, 1084-1087 (2001)

11. P.L. Smedley, D.G. Kinniburgh, Appl Geochem, 17, 517-568 (2002)

12. Y. Masue, et al., Env Sci Technol, 41, 3-837 (2007)

13. J.H. Long, et al., Chinese J Geotech Eng, 29, 2-38 (2007) 